Потеряйко Сергій Петрович кандидат військових наук, доцент, заступник начальника науково-організаційного відділу, Інститут державного управління та наукових досліджень 3 цивільного захисту, вул. Вишгородська, 21, м. Київ, 04074, тел. (044) 430-06-15, e-mail: sergiy_kiev@ukr.net, https://orcid.org/0000-0002-3787-0929

\title{
ГЕНЕЗИС ОРГАНІЗАЦЙНО-ФУНКЦІОНАЛЬНИХ СТРУКТУР ДЕРЖАВНОГО УПРАВЛІННЯ ЦИВІЛЬНИМ ЗАХИСТОМ ЩОДО ЗАБЕЗПЕЧЕННЯ ДЕРЖАВНОЇ БЕЗПЕКИ УКРАЇНИ
}

Анотація. У статті проведено аналіз генезису організаційнофункціональних структур державного управління цивільним захистом щодо забезпечення державної безпеки та окреслено напрями їх розвитку.

Проведено аналіз умов утворення організаційно-функціональних структур державного управління цивільним захистом щодо забезпечення державної безпеки протягом новітньої історії України та результати їх функціонування за цей період, виявлено тенденції, закономірності та визначено напрями щодо удосконалення зазначених структур.

Виокремлено три періоди утворення та діяльності організаційнофункціональних структур цивільного захисту, узагальнено кількість надзвичайних ситуацій, загиблих й постраждалих громадян України внаслідок їх виникнення за час існування безпекових структур.

Акцентовано на вагомості діяльності центральних, місцевих органів виконавчої влади, органів місцевого самоврядування в забезпеченні державної безпеки загалом, і збереженні життя, здоров’я та майна громадян зокрема.

Запропоновано узагальнений показник дієвості систем цивільного захисту та національної безпеки, що утворювались та функціонували в Україні, - зниження ризику виникнення надзвичайних ситуацій до рівня мінімально допустимого, збільшення кількості врятованих громадян України внаслідок надзвичайних ситуацій та кризових явищ, а також зменшення матеріальних збитків.

Визначено основні напрями удосконалення державного управління безпековими організаційно-функціональними структурами, зокрема: розвиток систем раннього виявлення загрози виникнення надзвичайних ситуацій, оповіщення та інформування, удосконалення системи управління безпекових організаційно-функціональних структур, утворення багатофункціональних безпекових формувань, здатних якісно виконувати широкий спектр функцій та завдань в нинішніх безпекових умовах, удосконалення системи підготовки органів управління та сил сектору безпеки та оборони, спрямування системи підготовки населення до дій в 
умовах надзвичайних ситуацій та кризових явищ на практичну складову частину.

Ключові слова: державне управління, безпекові структури, надзвичайна ситуація, цивільний захист, показник дієвості.

Poteryaiko Sergiy Petrovich Candidate of Military Science (PhD in Military Science), Associate Professor, Deputy Chief of the Research Department, Institute of Public Administration and Research in Civil Protection, Vishhorodska St., 21, Kyiv, 04074, tel.: (044) 430-06-34, e-mail: sergiy_kiev@ukr.net, https://orcid.org/0000-0002-3787-0929

\section{ORGANIZATIONAL AND FUNCTIONAL STRUCTURES OF PUBLIC ADMINISTRATION'S GENESIS OF CIVIL PROTECTION FOR UKRAINE'S STATE SECURITY}

Abstract. The analysis of organizational and functional structures of public administration's genesis of civil protection for Ukraine's state security is carried out in the article and outlines the directions of their development.

The analysis of the organizational and functional structures of public administration's genesis of civil protection formation conditions during the Ukraine's recent history and the results of their operation during this period, identified trends, patterns and identified areas for improvement of these structures are presents in the article.

Three periods of the organizational and functional structures of public administration's genesis of civil protection's formation and activity are singled out. The number of emergency situation, dead and injured Ukraine's citizens as a result of emergency situation during the existence of security structures is generalized.

Importance of the central, local executive bodies' and local self-government bodies' activities in ensuring Ukraine's state security in general, and the preservation of life, health and property of citizens in particular is outlined.

The generalized indicator of the civil protection's systems and national safety efficiency which were formed and functioned in Ukraine is proposed. This indicator includes reducing the risk of emergency situation to the minimum allowable level, increasing the number of rescued Ukraine's citizens as a result of emergency situation and crises and reducing material losses.

The main directions of improvement of public administration of security's organizational and functional structures are determined, in particular: development of early detection systems of the threat of emergency situations, notification and information, improvement of managements of security's organizational and functional structures, creation of multifunctional security formations capable of qualitatively performing a wide range of functions and tasks in the current security conditions, improving the training's system of governing bodies and forces of the security and defense sector, directing the system of preparing the population for 
action in emergency situation and crises on a practical component.

Keywords: public administration, security's structures, state security, emergency situation, civil protection, efficiency indicator.

Постановка проблеми. Утворення i ствердження України як демократичної, незалежної та суверенної держави пов'язано насамперед із забезпеченням іiі національної безпеки. Нині спостерігається небезпечна тенденція з боку країни-агресора щодо перегляду національних кордонів України поза нормами міжнародного права, де застосування сили підриває довіру міжнародним відносинам, зокрема в Свропі.

Водночас складними залишаються і внутрішні виклики національній безпеці, зокрема - стан єдиної державної системи цивільного захисту (далі ЄДСЦ3). Отже, сучасні виклики та загрози територіальній цілісності й незалежності держави, внутрішній безпеці суспільства зумовили актуальність питання щодо трансформації організаційно-функціональних структур сектору безпеки i оборони, що здатні протидіяти зовнішнім та внутрішнім загрозам. Зазначене завдання, вважаємо, може бути вирішене, зокрема, завдяки аналізу генезису організаційно-функціональних структур державного управління цивільним захистом (далі - ЦЗ) щодо забезпечення державної безпеки та окресленню напрямів їх розвитку.

Отже, пошук закономірностей розвитку державного управління безпековими організаційно-функціональними структурами та напрямів їх удосконалення нині є актуальним науковим завданням.

Аналіз останніх досліджень і публікацій. Науковим розвідкам щодо визначення історичних джерел створення та розвитку державного управління ЦЗ присвячено низку наукових досліджень вчених у зазначеній галузі науки.

Абрамов B.I, Андреєв С.О., Ситник Г.П. та ін. зазначають, що нині в Україні існує низка факторів, що лімітують підвищення ефективності діяльності системи державного управління щодо запобігання та боротьби 3 надзвичайними ситуаціями (далі - НC) різного характеру, серед яких автори відзначають, зокрема: відсутність реальної системи моніторингу НС, що функціонує, необхідних наукових досліджень, розробок, обмеженість кадрів необхідної кваліфікації, недосконалість всеосяжного освітнього процесу для всіх верст населення, недостатня відпрацьованість взаємодії ДСНС 3 Міноборони, МВС та ін. [1, С. 738-739].

Окреслені науковцями проблеми, на нашу думку, висвітлюють недосконалість організаційно-функціональних структур системи національної безпеки загалом, i Ц3 - зокрема щодо забезпечення національної безпеки.

В. Антонов дослідив генезис загальної теорії національної безпеки. Вчений зазначив, що безпекові проблеми наразі $\epsilon$ головним стрижнем досліджень, що розглядаються або через призму виникнення конфлікту, який визначає політику країни, або через систему взаємодії держав [2, С. 54].

С. Андреєв обгрунтував твердження, що інституціональний підхід до розвитку державних систем ЦЗ базується на взаємозалежності та 
взаємозв'язку двох основних складових - інституційної та нормативноправової, які є базовими елементами, що формуються суспільством i державою з метою якомога ефективнішого забезпечення захисту від загроз, пов'язаних із ризиком виникнення різних НС [3, С.17].

Вважаємо, що зазначені питання необхідно розглядати 3 позиції структурно-функціонального аналізу сфери державної безпеки та ЦЗ. У зв'язку із зазначеним, констатуємо, що автор частково розглядає питання щодо визначення місця та ролі ЦЗ в системі національної безпеки, структурні та їх функціональні зв'язки.

К. Бєлікова запропонувала загальну структуру системи управління в Ц3, що містить сукупність органів управління ЦЗ та системи інформаційноаналітичного забезпечення Ц3, яка $\epsilon$ інформаційним інструментарієм досягнення цілей державного управління у зазначеній сфері [4, С. 21].

А. Любінський розглянув особливості й сучасні тенденції модернізації системи Ц3 України, окреслив перспективні напрямки вдосконалення державного управління в цій сфері [7, С. 104]. Вчений зазначає, що підвищення ефективності діяльності ДСНС в умовах складної ситуації природного, техногенного спрямування та терористичних проявів вимагають перегляду та упорядкування теперішньої структури та складу наявних підрозділів ДСНС, їх оснащення, підготовка органів управління та сил ЦЗ [5, С. 105-106].

Аналіз досвіду побудови, функціонування та управління системами ЦЗ у забезпеченні національної безпеки країн-членів СС провів А. Рогуля, який розглянув особливості систем ЦЗ Німеччини, Італії, Франції, Швеції, Австрії, Угорщини, Польщі, Словаччини, Чехії [6, С. 130]. Автор зазначає, що система ЦЗ відіграє все більшу роль у забезпеченні національної безпеки європейських країн і стає предметом висхідної уваги у рамках міжнародних структур європейської безпеки. Моделі Ц3 країн СС різняться між собою, однак мають спільні основоположні цілі і принципи - попередження, боротьба 3 наслідками i відновлення після природних i техногенних катастроф, незалежно від причин їх виникнення 3 метою захисту невіддільних прав і свобод громадян, їх власності, демократичного устрою держави і ринкових засад економіки [6, С. 137].

Отже, встановлено, що нині у вчених єдиної думки щодо комплексного оцінювання генезису організаційно-функціональних структур державного управління ЦЗ щодо забезпечення державної безпеки не сформовано, тому зазначена проблема потребує більш детального наукового дослідження.

Мета статті - дослідити генезис організаційно-функціональних структур державного управління ЦЗ щодо забезпечення державної безпеки та окреслити напрями їх розвитку.

Виклад основного матеріалу. Для досягнення мети дослідження вважаємо необхідним провести аналіз утворення організаційнофункціональних структур державного управління ЦЗ щодо забезпечення державної безпеки протягом новітньої історії України та порівняти результати їх функціонування у певному історичному відрізку часу існування 
нашої держави, виявити тенденції, закономірності розвитку та визначити напрями щодо удосконалення зазначених структур.

Отже, проведемо генезис організаційно-функціональних структур державного управління ЦЗ щодо виконання функцій та завдань на основі статистичних даних діяльності вказаних структур та аналізу законодавства України у сферах ЦЗ та національної безпеки протягом останніх десятиліть в новітній історії України.

Законом України від 03.02.1993 № 2974-XII "Про цивільну оборону" визначено, що цивільна оборона України $\epsilon$ державною системою органів управління, сил і засобів, що створюється для організації та забезпечення захисту населення від наслідків НС техногенного, екологічного, природного та воєнного характеру. Постановою Кабінету Міністрів України від 10.05.1994 № 299 затверджено Положення про цивільну оборону України (зазначені законодавчі акти втратили чинність).

Постановою Кабінету Міністрів України від 03.08.1998 № 1198 затверджено Положення "Про єдину державну систему запобігання i реагування на надзвичайні ситуації техногенного та природного характеру" (втратила чинність).

Законом України “Про захист населення і територій від надзвичайних ситуацій техногенного та природного характеру” від 08.06.2000 № 1809-III введено в дію систему захисту населення і територій від НС техногенного та природного характеру - як систему організаційних, технічних, медикобіологічних, фінансово-економічних та інших заходів щодо запобігання та реагування на НС техногенного та природного характеру i ліквідації їх наслідків (втратив чинність).

Законом України від 24.06.2004 № 1859-IV “Про правові засади цивільного захисту" утворено єдину державну систему ЦЗ населення і територій - як сукупність органів управління, сил та засобів центральних i місцевих органів виконавчої влади, органів місцевого самоврядування, на які покладається реалізація державної політики у сфері ЦЗ (втратив чинність).

Зазначені законодавчі акти втратили чинність після затвердження Кодексу цивільного захисту України від 02.10.2012 № 5403-VI [7]. Також, слід зазначити, що Постановою Кабінету Міністрів України від 9 січня 2014 р. № 11 затверджено “Положення про єдину державну систему цивільного захисту" [8].

Отже, протягом новітньої історії України у сферах національної безпеки та ЦЗ функціонували такі системи, а саме:

з 1993 по 1998 роки в Україні функціонувала система цивільної оборони (далі - СЦО);

у 1998 році утворено єдину державну систему запобігання і реагування на НС техногенного та природного характеру (далі - ЄДСЗРНС);

у 2000 році утворено систему захисту населення і територій від НС техногенного та природного характеру (далі - СЗНТНС);

у 2004 році утворено єдину державну систему Ц3 населення і територій (далі - ЄДСЦЗНТ). Зазначені системи функціонували послідовно й 
одночасно з 1998 по 2014 роки.

Починаючи з 2014 року та по теперішній час функціонує ЄДСЦЗ.

Отже, процес утворення та функціонування безпекових організаційнофункціональних структур в новітній історії України можливо поділити на три періоди, а саме: 1993-1998 роки - СЦО; 1998-2014 роки - ЄДСЗРНС, СЗНТНС, СДСЦЗНТ; 2014 - по т.ч. - СДСЦЗ.

Вагому роль в безпеці держави відіграють центральні та місцеві органи виконавчої влади, органи місцевого самоврядування.

Державна служба України з надзвичайних ситуацій (далі - ДСНС) $є$ центральним органом виконавчої влади, діяльність якого спрямовується i координується Кабінетом Міністрів України через Міністра внутрішніх справ України і який реалізує державну політику у сфері ЦЗ, захисту населення і територій від НС та запобігання їх виникненню, ліквідації наслідків НС, рятувальної справи, гасіння пожеж, пожежної та техногенної безпеки, діяльності аварійно-рятувальних служб, а також гідрометеорологічної діяльності. Розглянемо результати діяльності ДСНС у 2020 році, що спрямовувалася на виконання актів законодавства, Президента України, Програми діяльності Кабінету Міністрів України, відповідних рішень Уряду у сфері повноважень ДСНС та виконання пріоритетних завдань [9].

Кількісні показники НС, що виникли у 2020 році, у порівнянні 3 2019 роком наведено у табл. 1.

Таблиия 1

Кількісні показники НС, що виникли у 2020 році, порівняно з 2019 роком

\begin{tabular}{|c|c|c|}
\hline Дані про НС & 2019 рік & 2020 рік \\
\hline 1 & 2 & 3 \\
\hline Загальна кількість НС: & 146 & 116 \\
\hline \multicolumn{3}{|l|}{ Зокрема за характером: } \\
\hline Техногенного & 60 & 47 \\
\hline Природного & 81 & 64 \\
\hline Соціального & 5 & 5 \\
\hline \multicolumn{3}{|l|}{ Зокрема за рівнями: } \\
\hline Державного & 2 & 6 \\
\hline Регіонального & 7 & 4 \\
\hline Місцевого & 63 & 50 \\
\hline Об’єктового & 74 & 56 \\
\hline Загинуло людей внаслідок НС & 200 & 170 \\
\hline Постраждало людей внаслідок НС & 1492 & 305 \\
\hline Матеріальні збитки від НС, тис. грн. & 1626730 & 9916677 \\
\hline
\end{tabular}

У 2020 році зафіксовано найменшу кількість НС за період спостережень, починаючи з 1997 року, натомість збільшилася масштабність НС та зафіксовано зростання більш ніж у 6 разів суми завданих НС збитків, насамперед унаслідок НС, пов'язаних із лісовими пожежами, а також НС унаслідок паводка. 
Вагомим чинником для визначення ступеню ефективності систем ЦЗ та державної безпеки України $є$ результати аналізу динаміки виникнення кризових явищ та НС, їх наслідків протягом новітньої історії України, коли утворювались, функціонували та трансформувались організаційнофункціональні безпекові структури.

Показовим $є$ аналіз динаміки виникнення НC, кількісні показники загиблих та постраждалих від їх наслідків протягом 2011-2020 років, що наведено на рис. $1,2$.

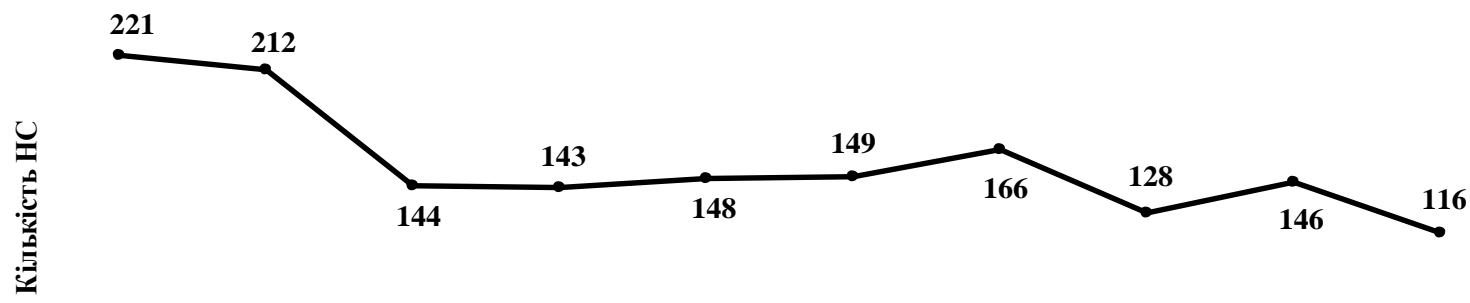

\begin{tabular}{|lllllllllll}
\hline 2011 & 2012 & 2013 & 2014 & 2015 & 2016 & 2017 & 2018 & 2019 & 2020
\end{tabular}

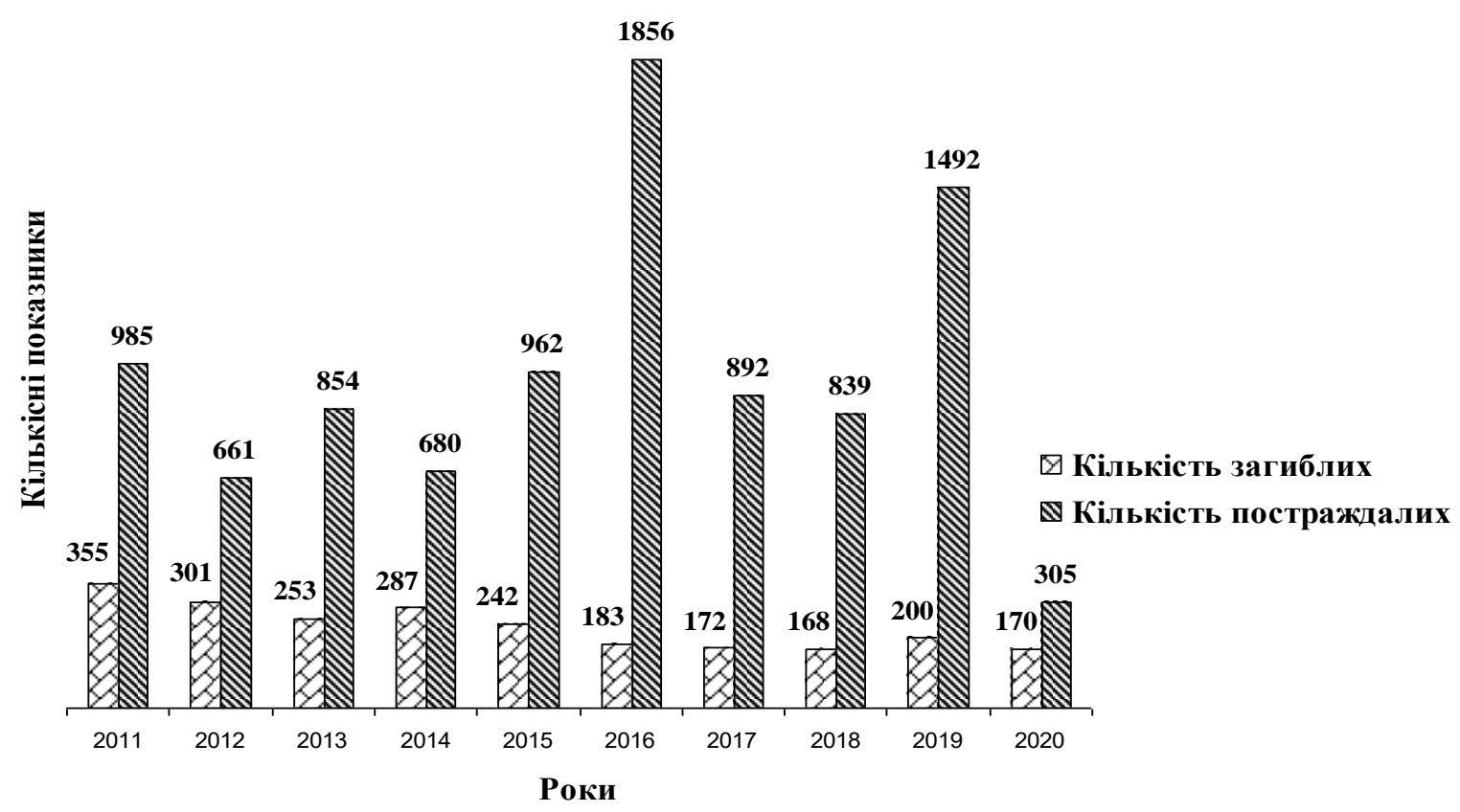

Pис. 2. Кількісні показники загиблих та постраждалих від наслідків НС протягом 2011-2020 років 


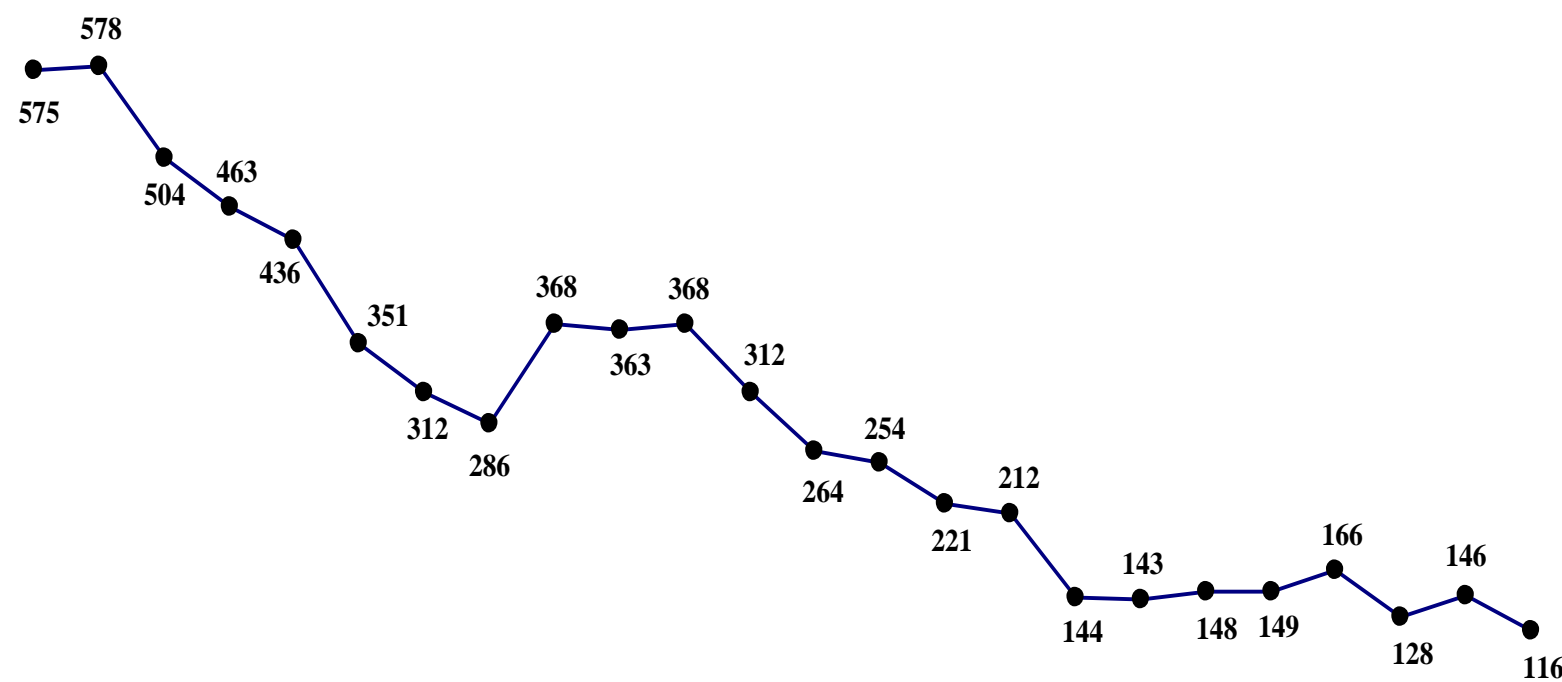

199719981999200020012002200320042005200620072008200920102011201220132014201520162017201820192020

СЦО ЄДСЗРНС, СЗНТНС, ЄДСЦЗНТ єДСЦЗ

Рис. 3. Узагальнені показники кількості НС, щзо виникли в Україні протягом 1997-2020 років

За результатами поглибленого аналізу виникнення НС та їх наслідків у роботі узагальнено показники кількості НС, що виникли в Україні протягом 1997-2020 років (див. рис. 3), їх наслідків (див. рис. 4) за періодами утворення та функціонування організаційно-функціональних структур сфери ЦЗ та державної безпеки.

У роботі проведено аналіз статистичних даних та встановлено чисельні показники щодо кількості НС, загиблих та постраждалих, протягом часу функціонування зазначених систем, а саме:

СЦО за 1997-1998 роки (з часу, коли здійснювався облік статистичних даних): НC - 1153 (576*); загиблих - 952 (476*) осіб; постраждалих - 6254 $\left(3127^{*}\right)$ осіб;

ЄДСЗРНС, СЗНТНС, СДСЦЗНТ протягом 1998-2014 років: НС - 4604 $\left(307^{*}\right)$; загиблих - 6128 (408*) осіб; постраждалих - 22801 (1520*) осіб;

ЄДСЦЗ протягом 2014-2020 років: НС - 995 (142*); загиблих - 1425 (203*) осіб; постраждалих - 1527 (218*) осіб.

В дужках із зірочкою позначено середнє значення показників за роки функціонування систем, що досліджуються, які складають:

1997-1998 роки СЦО - перший період, (рис. 1): НС - 576; загиблих 476; постраждалих - 3127. 
1998-2014 роки ЄДСЗРНС, СЗНТНС, СДСЦЗНТ - другий період (рис. 1): НС - 307; загиблих - 408; постраждалих - 1520.

2014-2020 ЄДСЦ3 - третій період (рис. 1): НС - 142; загиблих - 203; постраждалих - 218.

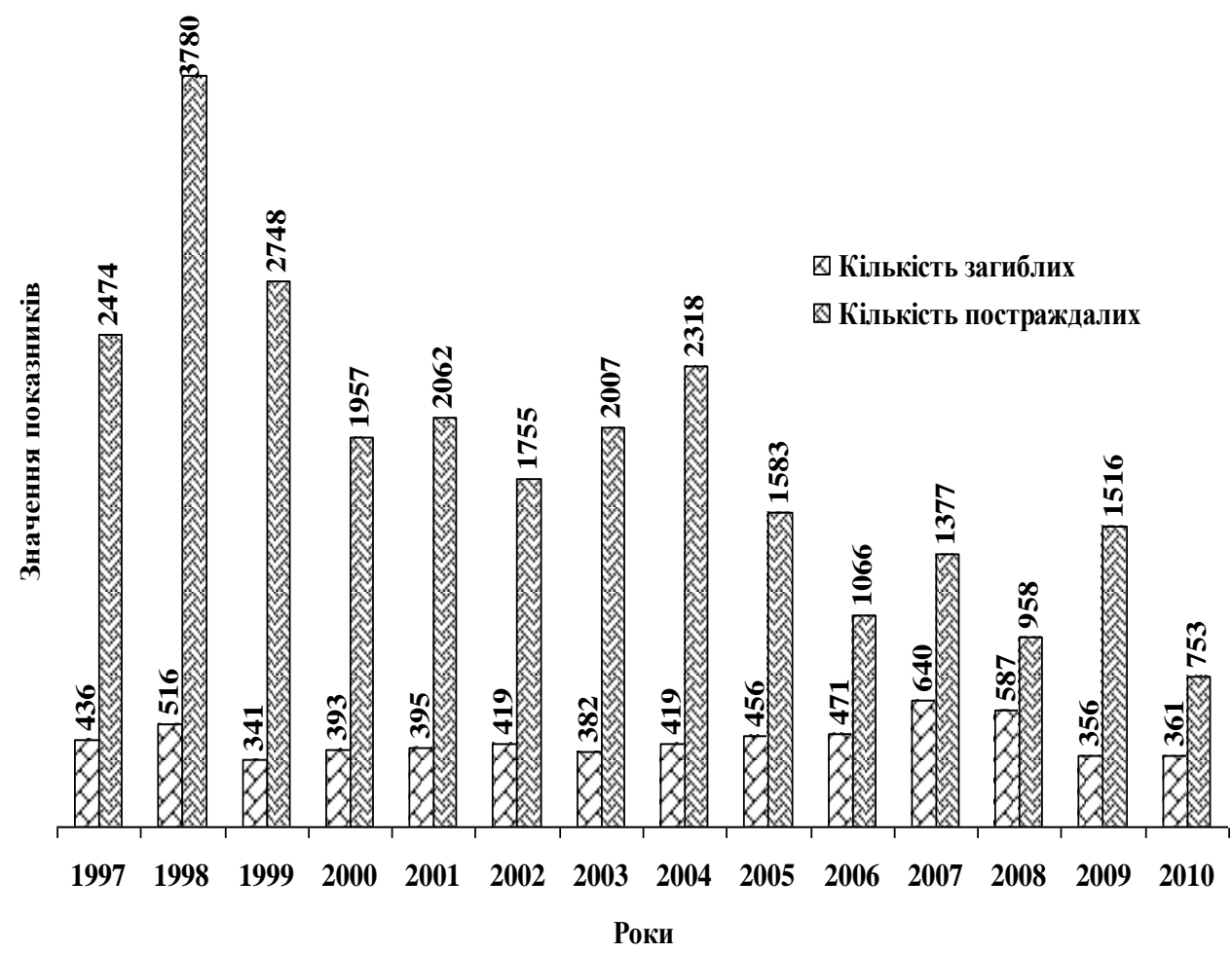

Pис. 4. Кількість загиблих і постраждалих унаслідок виникнення НС в Украӥні протягом 1997-2010 років

Усереднені показники кількості НС, загиблих та постраждалих внаслідок їх виникнення протягом 1997-2020 років наведено на рис. 5 . 


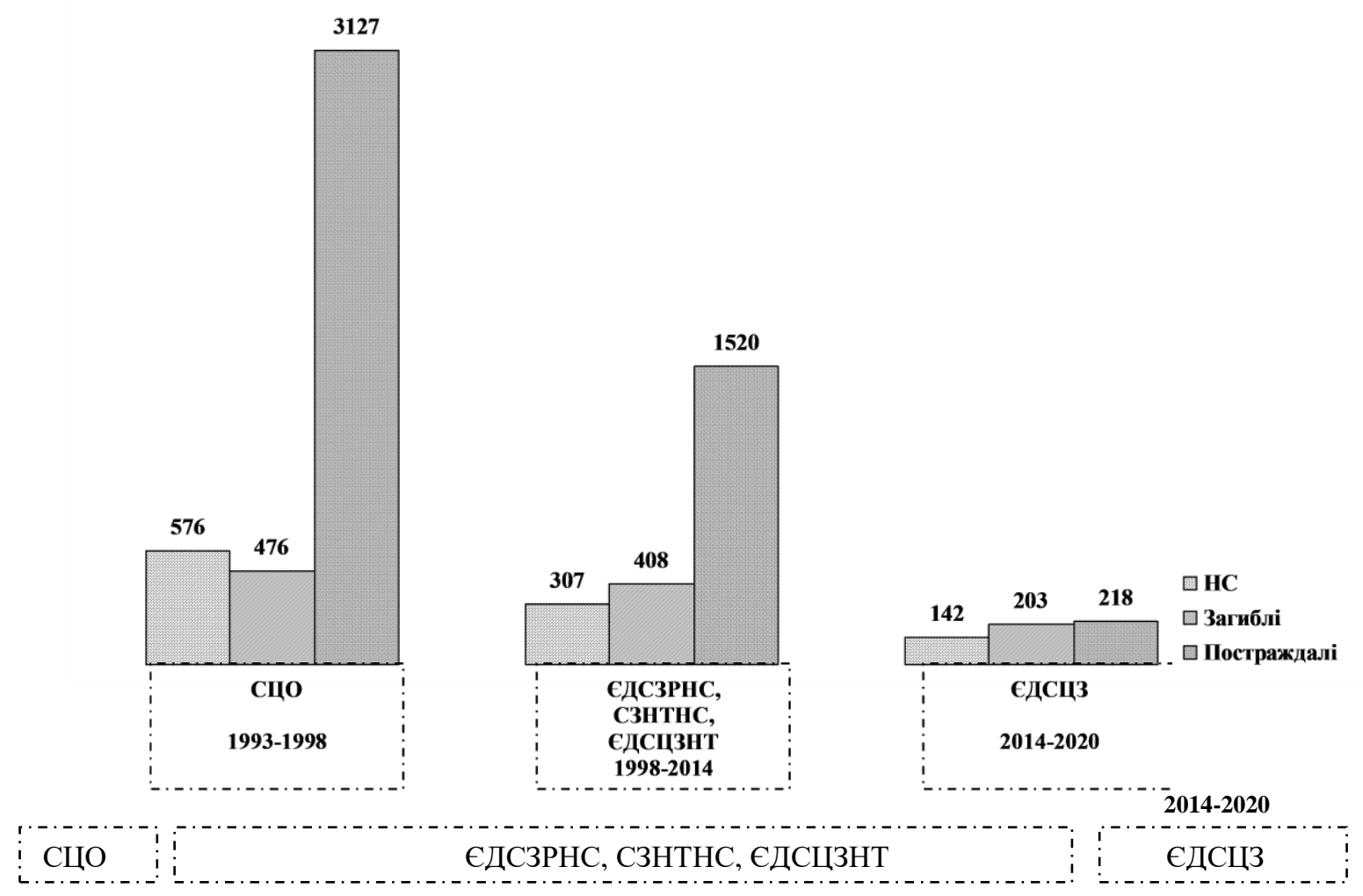

Pис. 5. Усереднені показники кількості НС, загиблих та постраждалих внаслідок їх виникнення протягом 1997-2020 років

Аналіз усереднених показників (див. рис. 5) свідчить про зменшення зазначених показників у третьому періоді функціонування безпекових структур, що, на наш погляд, пов'язано зі зменшенням рівня техногенного навантаження країни внаслідок скорочення кількості промислових об'єктів, а також оптимізацією безпекових організаційно-функціональних структур, зокрема сфери ЦЗ. Однак, слід зазначити про значне збільшення матеріальних збитків в економіці держави внаслідок виникнення НС та кризових явищ у 2020 році. Отже, нинішня ЄДСЦЗ, на наш погляд, потребує суттєвої організаційнофункціональної та структурної перебудови.

Відповідно до статті 3 Конституції України людина, іiі життя і здоров'я, честь і гідність, недоторканність і безпека визнаються в Україні найвищою соціальною цінністю [10]. Тому, вважаємо основоположним узагальненим показником дієвості систем ЦЗ та національної безпеки, що утворювались та функціонували в Україні, є зниження ризику виникнення НС до рівня мінімально допустимого, збільшення кількості врятованих громадян України внаслідок НС та кризових явищ, а також зменшення матеріальних збитків.

Висновки. Окреслено актуальне наукове завдання щодо дослідження генезису організаційно-функціональних структур державного управління ЦЗ із забезпечення державної безпеки та окреслити напрями їх розвитку.

Проведено аналіз умов утворення організаційно-функціональних структур державного управління ЦЗ щодо забезпечення державної безпеки протягом новітньої історії України та результати їх функціонування за цей 
удосконалення зазначених структур.

Виокремлено три періоди утворення та функціонування організаційнофункціональних структур ЦЗ та узагальнено кількість НС, що виникли, кількість загиблих й постраждалих громадян України за час діяльності безпекових структур.

Акцентовано на вагомості діяльності центральних, місцевих органів виконавчої влади, органів місцевого самоврядування в забезпеченні державної безпеки загалом, і збереженні життя, здоров’я та майна громадян зокрема.

Сформульовано висновок про покращення дієвості організаційнофункціональних структур ЦЗ протягом 1997-2020 років у третьому періоді на основі зменшення усереднених часткових показників, що пов'язане зі зменшенням рівня техногенного навантаження країни внаслідок скорочення кількості промислових об'єктів, а також оптимізацією безпекових організаційно-функціональних структур, зокрема сфери ЦЗ.

Запропоновано основоположний узагальнений показник дієвості систем Ц3 та національної безпеки, що утворювались та функціонували в Україні, зниження ризику виникнення $\mathrm{HC}$ до рівня мінімально допустимого, збільшення кількості врятованих громадян України внаслідок НС та кризових явищ, а також зменшення матеріальних збитків.

Визначено основні напрями удосконалення державного управління безпековими організаційно-функціональними структурами, а саме:

розвиток систем раннього виявлення загрози виникнення НС, оповіщення та інформування органів державного управління та населення про загрозу та виникнення НС й кризових явищ із використанням новітніх технологій;

удосконалення системи управління безпекових організаційнофункціональних структур шляхом оснащення сучасними засобами отримання й передачі інформації, їх оптимізації та інтегрування за єдиним функціоналом;

утворення багатофункціональних безпекових формувань, здатних якісно виконувати широкий спектр функцій та завдань в нинішніх безпекових умовах;

удосконалення системи підготовки органів управління та сил сектору безпеки та оборони за єдиними планами й можливими сценаріями виникнення та розвитку кризових явищ;

спрямування системи підготовки населення до дій в умовах $\mathrm{HC}$ та кризових явищ на практичну складову частину із урахуванням особливостей їх виникнення в конкретному регіоні.

Подальшим напрямом наукових досліджень за зазначеною проблематикою вбачається у визначенні наукових підходів до прогнозування діяльності організаційно-функціональних безпекових структур щодо забезпечення державної безпеки. 


\section{Лimepamypa:}

1. Абрамов В. І., Ситник Г. П., Смолянюк В. Ф. та ін. Глобальна та національна безпека: підруч. / НАДУ. Київ, 2016. 784 с.

2. Антонов В. О. Конституційно-правові засади національної безпеки України: монографія / ТАЛКОМ. Київ, 2017. 576 с.

3. Андреєв С. О. Інституціональні засади розвитку державних систем цивільного захисту : дис. ... д-ра наук держ. упр. : спец. 25.00.02 "Механізми державного управління" / Нац. акад. держ. упр. при Презид. Укр. Київ, 2017. 552 с.

4. Бєлікова К. Г. Теоретико-методологічні засади функціонування та розвитку системи інформаційно-аналітичного забезпечення цивільного захисту України : автореф. дис. ... д-ра наук держ. упр. спец. 25.00.02. "Механізми державного управління” / МАУП. Київ, 2021. 40 с.

5. Любінський А. М. Сучасний стан та перспективи модернізації системи цивільного захисту України. Ефективність державного управління : зб. наук. пр. Львів : ЛРІДУ НАДУ. 2015. Вип. 43. С. 104-109.

6. Рогуля А. О. Свропейський досвід функціонування системи цивільного захисту населення у забезпеченні національної безпеки. Ефективність державного управління : зб. наук. пр. 2015. - Вип. 45. С. 130-138.

7. Кодекс цивільного захисту України: Закон України від 2.10.2012№ 5403-VI // База даних “Законодавство України” / BP України. URL : https://zakon.rada.gov.ua/laws/ show/5403-17\#Техt (дата звернення: 01.06.2021).

8. Про затвердження Положення про єдину державну систему цивільного захисту : постанова Кабінету Міністрів України від 9.01.2014 № 11 // База даних “Законодавство України” / ВР України. URL : https://zakon.rada.gov.ua/laws/show/11-2014-\%D0\%BF\#Text (дата звернення: 01.06.2021).

9. Звіт про основні результати діяльності Державної служби України з надзвичайних ситуацій у 2020 році : URL : https://www.dsns.gov.ua/files/2021/1/26/\%D0\%BF\%D1\%83\% D0\%B1\%D0\%BB\%D1\%96\%D1\%87\%D0\%BD\%D0\%B8\%D0\%B9\%20\%D0\%B7\%D0\%B2\% D1\%96\%D1\%82\%20\%D0\%93\%D0\%BE\%D0\%BB\%D0\%BE\%D0\%B2\%D0\%B8\%202020\%2 0\%D0\%BE\%D1\%81\%D1\%82\%D0\%B0\%D1\%82\%D0\%BE\%D1\%87\%D0\%BD\%D0\%B8\%D0 \%B9\%202.pdf (дата звернення 01.06.2021).

10. Конституція України: Закон України від 28.06.1996 // База даних “Законодавство України" / ВР України. URL : https://zakon.rada.gov.ua/laws/show/254\%D0\%BA/96-\% D0\% B2\%D1\%80\#Text (дата звернення: 01.06.2021)

\section{References:}

1. Abramov, V.I., Sytnyk, H.P., Smolianiuk, V.F., et al. (2016). Hlobalna ta natsionalna bezpeka [Global and national security]. Kyiv: NADU [in Ukrainian].

2. Antonov, V.O. (2017). Konstytutsiino-pravovi zasady natsionalnoi bezpeky Ukrainy [Constitutional and legal principles of national security of Ukraine]. Kyiv: TALKOM [in Ukrainian].

3. Andreiev, S.O. (2017). Instytutsionalni zasady rozvytku derzhavnykh system tsyvilnoho zakhystu [Institutional principles of development of state systems of civil protection]. Doctor's thesis. Kyiv: Nats. akad. derzh. upr. pry Prezyd. Ukr. [in Ukrainian].

4. Bielikova, K.H. (2021). Teoretyko-metodolohichni zasady funktsionuvannia ta rozvytku systemy informatsiino-analitychnoho zabezpechennia tsyvilnoho zakhystu Ukrainy [Theoretical and methodological principles of functioning and development of the system of information and analytical support of civil defense of Ukraine]. Extended abstract of Doctor's thesis. Kyiv: MAUP [in Ukrainian].

5. Liubinskyi, A.M. (2015). Suchasnyi stan ta perspektyvy modernizatsii systemy tsyvilnoho zakhystu Ukrainy [The current state and prospects of modernization of the civil 
defense system of Ukraine]. Efektyvnist derzhavnoho upravlinnia - Efficiency of public administration, 43, 104-109 [in Ukrainian].

6. Rohulia, A. O. (2015). Yevropeiskyi dosvid funktsionuvannia systemy tsyvilnoho zakhystu naselennia u zabezpechenni natsionalnoi bezpeky [European experience of the civil system protection of the population in ensuring national security]. Efektyvnist derzhavnoho upravlinnia - Efficiency of public administration, 45, 130-138 [in Ukrainian].

7. Zakon Ukrainy "Kodeks tsyvilnoho zakhystu Ukrainy" : vid 2.10.2012, № 5403-VI [Law of Ukraine "Code of Civil Protection of Ukraine" from 2.10.2012, № 5403-VI]. zakon.rada.gov.ua. Retrieved from https://zakon.rada.gov.ua/laws/show/5403-17\#Text [in Ukrainian].

8. Postanova Kabinetu Ministriv Ukrainy "Pro zatverdzhennia Polozhennia pro yedynu derzhavnu systemu tsyvilnoho zakhystu" : vid 9.01.2014, № 11 [Resolution of the Cabinet of Ministers of Ukraine "On approval of the Regulations on the unified state system of Civil Protection” from January 9 2014, № 11]. zakon.rada.gov.ua. Retrieved from https://zakon.rada.gov.ua/laws/show/11-2014-\%D0\%BF\#Text [in Ukrainian].

9. Zvit pro osnovni rezultaty diialnosti Derzhavnoi sluzhby Ukrainy z nadzvychainykh sytuatsii u 2020 rotsi [Report on the main results of the Civil Service of Ukraine for Emergencies in 2020]. (n.d.). www.dsns.gov.ua. Retrieved from https://www.dsns.gov.ua/files/2021/1/26/ публічний\%20звіт\%20Голови\%202020\%20остаточний\%202.pdf [in Ukrainian].

10. Zakon Ukrainy "Konstytutsiia Ukrainy" : vid 28.06.1996 [Law of Ukraine "Constitution of Ukraine" from 28.06.1996]. zakon.rada.gov.ua. Retrieved from https://zakon.rada.gov.ua/laws/show/254\%D0\%BA/96-\%D0\%B2\%D1\%80\#Text [in Ukrainian]. 